\title{
KAYA ISLAHI ÇALIŞMALARINDA BİRLEŞİK ÇÖZÜMLERİN İNCELENMESİ: TRABZON KAYMAKLI ÖRNEĞİ
}

\author{
Mohammad Manzoor NASERY \\ Muhammet ÇELIK
}

Alınma: 26.01.2020; düzeltme: 22.02.2020; kabul: 13.03.2020

\begin{abstract}
Öz: Karadeniz bölgesi, Türkiye'nin en fazla kaya düşmesi yaşanan bölgelerindendir. Çalışmada incelenen alanda (Trabzon İli Kaymaklı Mahallesi) 16 metre yüksekliğinde 6 adet dik yamaçtan oluşan kaynak kayalıklar bulunmaktadır. Bu riskli kayalar 74 konutu, sanayi alanını ve devlet karayolunu etkilemektedir. Daha önce düşen kayalardan dolayı 2 vatandaş hayatını kaybetmiştir. Çalışmada, aktif olarak kaya düşme riski olan bölgede 1 slah çalışması ve önerilen birleşik sistemin etkinliği değerlendirilmiştir. Çalışma kapsamında arazinin üç boyutlu sayısal yüzey modeli oluşturulmuştur. Ardından bölgenin jeolojik etüdü yapılmış ve erişimsiz yamaçtaki riskli kayalar endüstriyel dağclar tarafından incelenmiştir. Bilgisayar ortamında arazi modeli üzerinden 40 adet kesit alınarak her bir kesit üzerine 50 farklı olasılıkla, toplamda ise 2000 adet kaya düşme analizi gerçekleştirilmiştir. Sonuçlar incelendiğinde düşen kayaların $11,7 \mathrm{~m}$ yüksekliğe kadar sıçrayabildiği ve $3000 \mathrm{~kJ}$ değerinde kinetik enerjiye ulaşabildiği tespit edilmiştir. Arazi koşulları nedeniyle ıslah yöntemlerinin birçoğu tek başına bölgede kullanılamamaktadır. Bu nedenle birkaç kaya ıslah yönteminin beraber kullanıldığı birleşik çözüm önerisi (BÇÖ) geliştirilmiştir. Oluşturulan çözümde enerji sönümleyici çelik bariyerler betonarme istinat duvar üzerine montajlanarak kaya düşmesi koruma yapısı oluşturulmuştur. Tehlikeli kayalar temizlenerek, sslah sisteminin ömrü uzatılmış, son olarak çelik ağ ile kaynak kayalıklar kapatılmıştır. Ağ sayesinde kaya düşmesi sırasında sıçrama yüksekliğinin tehlikeli boyutlara çıkması engellenmiștir. BÇÖ alternatifinden 3,2 kat daha az maliyetli olmakla beraber daha fazla güvenlidir.
\end{abstract}

Anahtar Kelimeler: Kaya düşmesi, Birleşik Kaya Islahı, Sıçrama Yüksekliği, Kinetik Enerji, Afet

\section{Investigating the Effectiveness of Combined Rockfall Protection System Solutions: Trabzon Kaymaklı Case}

\begin{abstract}
The area considered in this study is located in Kaymaklı neighborhood of Trabzon province. There were 6 zones with a possible rock fall risk having $16 \mathrm{~m}$ height that were threatening 74 houses, industrial areas and state roads. Two citizens have lost their lives due to rock fall incident in previous years. In this study, the effectiveness of the combined rockfall protection systems (CRPS) were assessed. Within the scope of the study, a three-dimensional surface model of the terrain was created. Following the geological survey of the region, the inaccessible risky zones were examined by industrial climbers. 40 cross sections were obtained from 3D model and 2000 rockfall analyzes were carried out. Obtained results indicate that bounce height and the kinetic energy can reach to $11.7 \mathrm{~m}$ and $3000 \mathrm{~kJ}$, respectively. According to results and the land conditions, many of the protection methods cannot solely respond to the problem in this region. Therefore, CRPS, where many rock fall protection methods are combined and used together, has been used. According to the CRPS, the energy absorbing barrier installed on the top of RCC retaining
\end{abstract}

\footnotetext{
* Karadeniz Teknik Üniversitesi, Kanuni Kampüsü, İnşaat Mühendisliği Bölümü 61080, Ortahisar/TRABZON

**Trabzon İl Afet ve Acil Durum Müdürlüğü, Rize Caddesi, Yalıncak Mah. 61220 Ortahisar/TRABZON

İletişim yazarı: Muhammet ÇELİK (m.celik53@gmail.com)
} 
wall. Furthermore, dangerous rocks were broken in a bid to extend the useful life of the system. Finally, to prevent the bounce height from escalating to dangerous level, risky blocks were covered with a steel wire net. CRPS is 3.2 times economically efficient and safety compared to the best alternative.

Keywords: Rockfall, Combined rockfall protection solutions, Bounce height, Kinetic energy, Disaster

\section{GÍRİs}

Kayalar, fiziksel veya kimyasal ayrışma gibi nedenlerden ve yerçekiminin etkisiyle bulundukları yüksek kotlardan daha alt kotlara doğru düşme hareketi gösterebilirler. Kayanın bulunduğu mevkilerde düşme hareketine geçmesinin en önemli nedenlerinden biri sudur (Matsuoka ve Sakai, 1999). Özellikle suyun kayalarda bulunan boşluklarda donması ve çözülmesi veya minerallerin fiziksel çözünmeleri, kayalardaki süreksizlikleri artırmaktadır (Terzaghi, 1950). Ayrıca iklim, deprem, yanlış şev açılması gibi çeşitli durumlar kaya düşmesi olayının bütün bölgelerde görülmesine neden olmaktadır. Düşmeye başlayan kayaların hızlarını artıran faktörlerden biri de şevleri kaygan hale getiren nem faktörüdür (Wei ve diğ., 2014). Kaya düşmesi olayına, genellikle nüfus yoğunluğunun daha az olduğu dağlık arazilerde rastlanmaktadır. Bunun yanı sıra, dağlık alanlardaki nüfusun çeşitli nedenlerden dolayı artması da kaya düşmesi durumunda insan yaşamı için risk oluşturmaktadır (Baillifard ve diğ., 2004). Daha az sıklıkla da olsa şehir merkezlerinde veya otoyol güzergahlarında kaya düşmesi durumunda da risk tehlikeli boyutlara ulaşmaktadır (Leroi ve diğ., 2005). Türkiye jeolojik ve jeomorfolojik özellikleri nedeniyle yüksek oranda dağlık araziye sahip bir ülkedir. Ancak ülke genelinde yerleşim birimleri oluşturulurken kaya düşmeleri dikkate alınmamıştır, bu nedenle bazı yerleşim birimlerinde kaya düşmesi afeti görülmektedir (Şahin ve Sipahioğlu, 2009; Alkan ve Dağ, 2018). Doğu Karadeniz Bölgesi, Türkiye'nin en fazla yağış alan bölgesi olduğundan suyun neden olduğu kaya düşmeleri oldukça sık görülmektedir. Bölgenin dağlık yapısı nedeniyle yerleşim veya tarım alanlarını oluşturan düz arazilerin az olmasından dolayı yamaçların eğiminin azaldığı alt kotlarında veya dere havzalarında daha çok yerleşim birimleri bulunmaktadır. Bu alanlar kayaların düşme güzergâhları olduğu için, bölgede kaya düşmesi sırasında insan hayatının tehlikeye girme olasılığı yüksektir (Öztürk ve Şahinöz, 2018). Eğimli arazilerin bir diğer dezavantajı da harekete geçen kayaların çok kısa sürede hızlarının artması ve çarpma anında daha yüksek enerji seviyelerine ulaşarak hasarlara neden olmalarıdır (Biricik, 2001). Bölgede su ve eğim faktörü dışında farklı nedenlerden dolayı da kaya düşmelerine rastlanılmaktadır. Örneğin ağaçların köklerinin büyümesi sırasında kayalarda süreksizlikler ve ayrışmaların oluşması (Yılmaz ve diğ., 2008) rüzgâr, yağmur veya erozyon nedeniyle kayaların bulunduğu alanlarda toprak akması veya ağaçların devrilmesi sırasında köklerde bulunan kayaların harekete geçmesi yaşanan vaka türlerine örneklerdir (Admassu ve diğ., 2012).

Kaya düşmesinin insan hayatını etkilediği alanlarda ıslah çalışmaları yapılarak, kaya düşmesi önleme ve koruma yöntemleri uygulanmaktadır. Günümüzde riskli blokların 1slahı çeşitli yöntemler ile yapılmaktadır. Düşme ihtimali bulunan kaya bloklarının yuvarlanma güzergâhlarında konut, işyeri vb. yapıların varlığı 1slah yöntemlerini zorlaştırmaktadır. Bu tarz durumlarda kaya ıslahı projelerinin maliyetleri de oldukça artmaktadır. Kaya ıslahı yönteminin belirlenmesinde en önemli faktörün emniyet kriteri olmasına rağmen ıslah projelerinin maliyetleri de emniyet kriteri kadar önem arz etmektedir. Buna göre yapılan ıslah çalışması hem emniyetli hem de maliyeti diğer alternatiflere göre uygun olacak şekilde seçilmelidir. Başka bir deyiş ile optimum özelliklere sahip kaya ıslahı yöntemini belirlemek oldukça önemlidir. Bu noktada kaya 1slahı yöntemleri arasında seçimin iyi yapılması, mühendislik analiz ve hesaplarında dikkatli olunması maliyetlerin düşürülmesinde oldukça önem arz etmektedir (Varnes, 1978). Kaya 1slahı çalışmalarında kaya ile ilgili birçok bilgi değerlendirilerek en uygun risk önleyen yöntemin seçilmesi gerekmektedir (Hutchinson, 1998).

Kaya düşmesi ıslah projelerinin yapılması sırasında doğru yöntemin seçilmesi için, kaya ile ilgili çeşitli bilgilerin toplanıldığı analizlerin dikkatlice yapılması gerekmektedir. Kayanın fiziksel ve 
mekanik özellikleri, süreksizlik durumu, düşme nedenleri, düşen blokların boyutları, düşme güzergâhları, düşme sırasında bloğun kazandığı hızı, sıçrama yüksekliği, kinetik enerjisi vb. gibi bilgiler, hazırlanacak kaya düşmesi sslah projesinin en uygun alternatifinin seçimi için oldukça önemlidir. Ayrıca kaya ıslah yöntemlerinin de genel olarak iyi bilinmesi doğru yöntemin seçilmesinde etkin rol oynamaktadır. Kaya 1slah yöntemleri genel olarak ikiye ayrılır; Kaya harekete geçmeden önce durdurma (aktif yöntemler) ve kayanın harekete geçmesine izin verilen ancak kontrollü şekilde durdurulan veya tehlikesiz alana nakledilen yöntem (pasif yöntemler) olarak adlandırılır (Turner ve Schuster, 2012). Aktif yöntemler kendi içerisinde, kaya bulonları, kaya çivisi, püskürtme beton, payanda, kablo ile sabitleme, ankrajlı çelik kafesler, tıraşlama, şevlendirme, blokların kontrollü kırılması gibi yöntemlerden oluşmaktadır (Wyllie ve Norrish, 1996). Pasif yöntem olarak da kaya tutma alanları veya hendekleri, esnek bariyerler, sabit bariyerler ve kafes sistemler kullanılmaktadır (Andrea ve diğ., 2016; Polat ve diğ., 2016).

$\mathrm{Bu}$ çalışmada Trabzon ili şehir merkezinde, konutların, sanayi tesisinin ve karayolunun bulunduğu bir alanda tehlike yaratan kayaların ıslahına yönelik yapılmış çalışma incelenmiştir. Değerlendirme yapılırken emniyet ve maliyet açısından en uygun yöntemler kullanılarak yamacın 1slah edilmesi hedeflenmiştir. Projelendirme kapsamında riskin daha iyi tespit edilebilmesi için dört aşamalı bir çalışma gerçekleştirilmiştir. İlk önce bölgenin genel jeolojik özellikleri ve kayanın fiziksel özellikleri belirlenmiştir. İkinci aşamada kaya düşme analizlerinde ve net metrajlarda kullanılmak üzere fotogrametrik yöntem ile arazinin üç boyutlu sayısal yüzey modeli oluşturulmuştur. Üçüncü aşamada bölgedeki riskli kayaların risk dereceleri ve olası düşme potansiyellerinin yakından incelenmesi için endüstriyel dağcılar tarafından inceleme yapılmıştır. Tehlikeli kaynak kaya bloklarının bulundukları yerler genellikle sarp kayalıklardan oluştukları için teknik personeller (mühendisler) tarafından tam olarak incelenememiştir. Bu durum proje yapımı sırasında yetersiz verilerin oluşmasına hatta yanlış tercihler yapılmasına neden olabilmektedir. Endüstriyel dağcı vasfina sahip elemanlar bu tarz bölgelerde emniyet ipiyle iniş yaparak rahatlıkla incelemelerde bulunmakta hatta fotoğraflayarak proje hazırlayan teknik personelin işini kolaylaştırmaktadırlar. Yakın incelemeler sırasında düşme tehlikesinin büyüklüğüne göre 1. ve 2. derecede riskli kayalar belirlenmiştir. 1. derece riskli kayalar düşme riski yüksek kayalar (yamaç ile bağlantıları neredeyse tamamen kesilmiş olan bloklar ve süreksizlikleri tamamen ayrılmış bloklar), 2. derece riskli kaya blokları ise düşme riski daha düşük (süreksizlikleri mevcut fakat genişlikleri daha az, riskli blokların yamaç ile belli bölgelerde bağlantıların mevcut olması) kayaları belirtmektedir. Belirlenen riskli kaya bloklarının kaya düşme analizleri gerçekleştirerek olası düşme sırasında sahip olacağı sıçrama yüksekliği, hız ve enerji gibi parametreleri hesaplanması da son aşamayı oluşturmuştur. Yapılan bu 4 aşamalı risk tespitine göre en güvenilir ve en ekonomik ıslah yöntemi seçilmeye çalışılmıştır. Çalışmanın son bölümünde ise; 1slah yönteminde kullanılan birleşik sistemlerin etkinlik ve uygulanabilirliği irdelenmiştir.

\section{YAPILAN ÇALIŞMALAR}

\section{1. Çalış̧ma Alanının İncelenmesi}

Kaya düşmesi 1slah projesinin hazırlanacağı ve daha önce afetin yaşandığg alan, Trabzon İli Ortahisar İlçesine bağlı Kaymaklı Mahallesinde bulunmaktadır. 21 Kasım 2009 tarihinde kaya düşmesi afeti nedeniyle 2 can kaybı yaşanmasıyla bölgede kaya düşmeleri takip edilmiş, muhtelif tarihlerde kaya düşmelerinin yaşandığı tespit edilmiş̧ir. Ayrıca bölgede düşen kayalar mal kaybına da neden olmaktadır. Kaya düşmesi tehlikeli boyutlarda ve sıklıkta olduğu durumlarda, 7269 Sayılı Umumi Hayata Müessir Afetler Dolayısıyla Alınacak Tedbirlerle Yapılacak Yardımlara Dair Kanun gereği afete maruz bölge ilanı yapılmaktadır. Buna göre afete maruz ilan edilen bölge imara ve iskâna kapatılır. Bu kanun kapsamında hazırlanan jeolojik etüt raporuna (JER) göre 11.12.2009 tarihinde Kaymaklı Mahallesinde afetin yaşandığı alan, afete maruz bölge olarak ilan edilmiştir. İlk JER raporunda 17 konut (Şekil 1/a), ikincisinde ise 57 konut toplamda 
74 konut afete maruz alan içerisinde kabul edilmiştir (Şekil 1/b). Afete maruz bölgede konutların yanı sıra Trabzon-Maçka-Erzurum devlet karayolu da afete maruz bölgeden geçmektedir (Şekil 2). Birçok iş yeri ve sanayinin bu bölgede olması nedeniyle, kaya düşmesi vakası yaşanması durumunda yaralanma hatta ölüm olayının gerçekleşme riski oldukça yüksektir. Bu nedenle proje imalat aşamasında gerekli önlemler alınarak inşaat çalışmaları yapılmalıdır. Belirtilen bölgede 6 adet kaya düşmesi kaynak zonu bulunmaktadır. Bu kaynak zonlar Şekil 3 'te görüldüğü gibi dik yamaç şeklinde bir yapıya sahiptirler. Bölge hakkında daha önce yapılan çalışmalar ve hazırlanan JER'lerde düşen kayaların yaklaşık 3-4 $\mathrm{m}^{3}$ büyüklükte olduğu belirtilmiştir. Arazide yapılan incelemelerde düşmüş kayaların da benzer boyutlarda olduğu görülmektedir. Arazide dik yamaçların hemen önü daha önce düşmüş blok ve yamaç molozu ile doludur. Ayrıca bu malzemelerin birkaç metre ilerisinde yerleşim birimleri bulunmaktadır. Arazide genellikle bodur bitki örtüsü hâkimken yer yer yüksek ağaçlar da mevcuttur. Özellikle kuzey tarafa doğru yüksek ağaçlar sıklaşmaktadır. Çalılık ve dikenlerden oluşan yüzey bitkileri kayaların ve çatlakların detaylı incelenmesini engellemektedir. Ayrıca dik yamaç ile evler arasındaki mesafenin az olması 1slah yapısının seçimindeki seçenekleri aza indirmektedir. Yamaç ve vadilerde çok fazla girinti çıkıntı olması, bölgedeki sıçrama yüksekliklerinin hesaplamasını doğrudan etkilemektedir. Paket programlar ile yapılan analizler sonucu elde edilen veriler ile çözüm önerilerinin belirlenmesi yapılmaktadır. Fakat arazinin aşırı derecede girintili çıkıntılı ve bitki örtüsü ile kaplı olduğundan sıçrama yüksekliğinde güvenlik faktörü göz önünde bulundurulmalıdır.

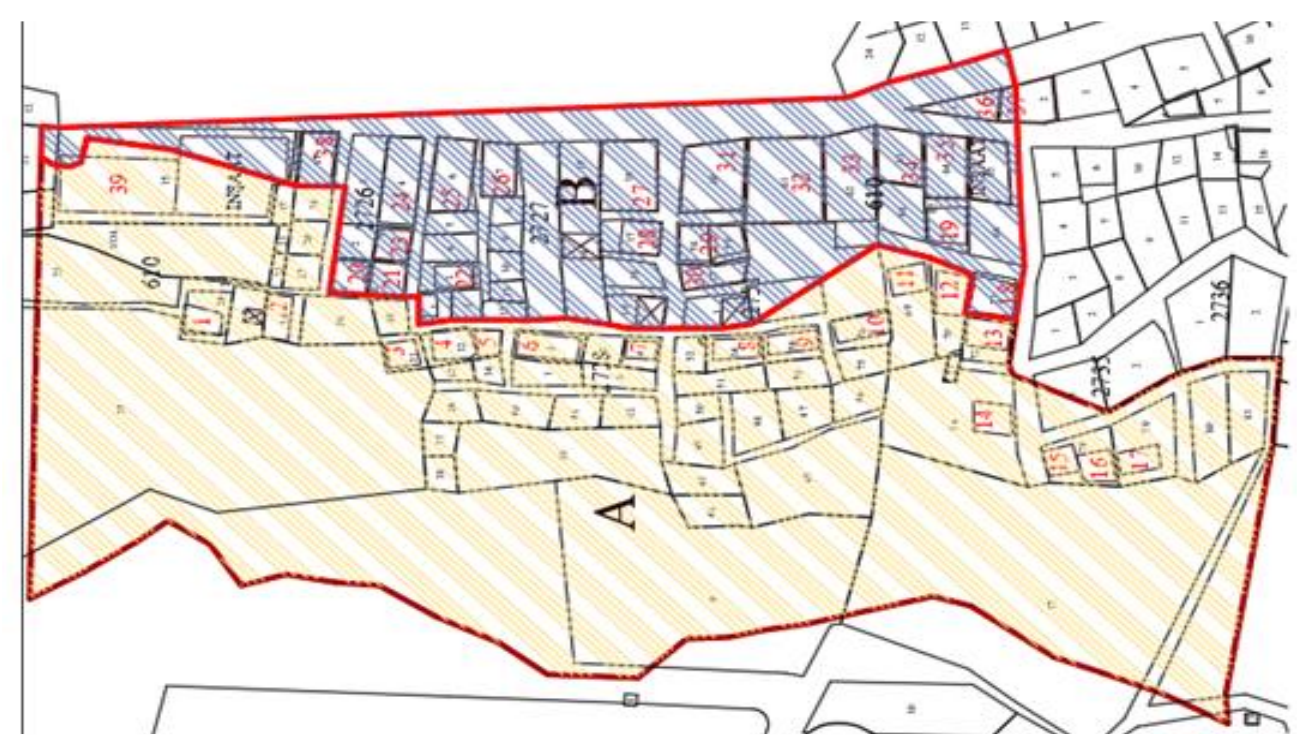

Şekil 1:

Afete maruz bölge

a. 1.JER Afeti Maruz Bölge b. 2. JER Afete Maruz Bölge 


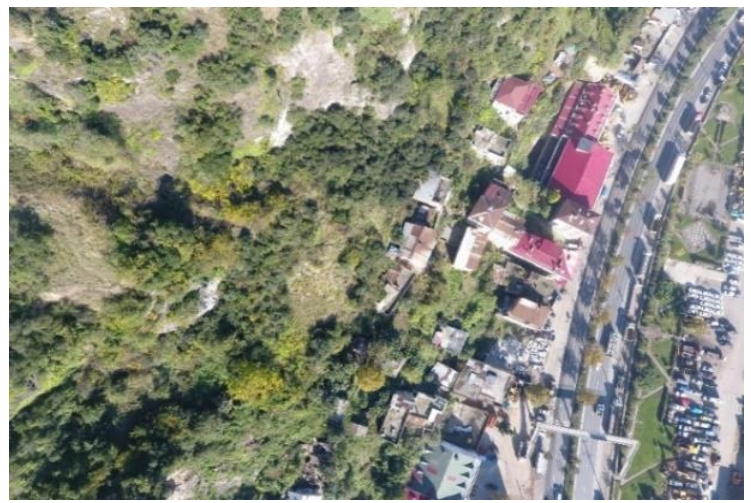

Şekil 2:

Kaya düşmelerinde etkilenen yapılar, Trabzon Maçka Erzurum Yolu ve kaynak kayalıklar

\section{2 Çalışma Alanının Genel Jeolojisi ve Kaya Malzemesinin Özellikleri}

Çalışma alanının Türkiye ve Trabzon İl haritasında yeri ve kaynak alandan çekilmiş görünümü Şekil 3'te görülmektedir. Etüt alanında şev yüzeylerinden yapılan gözlemler neticesinde Kabaköy Formasyonuna ait Eosen yaşlı bazaltların yer aldığı görülmüştür. Etüt alanındaki yamaç yüzeylerinde mostra veren bazalt birimi gri renkte olup, kırıklı, çatlaklı, yer yer sert ve sağlam özelliktedir. Bazalt üst seviyelerde parçalı, kırıklı, çatlaklı olup, alt kısımlara doğru masif özellik kazanmaktadır (Şekil 4).
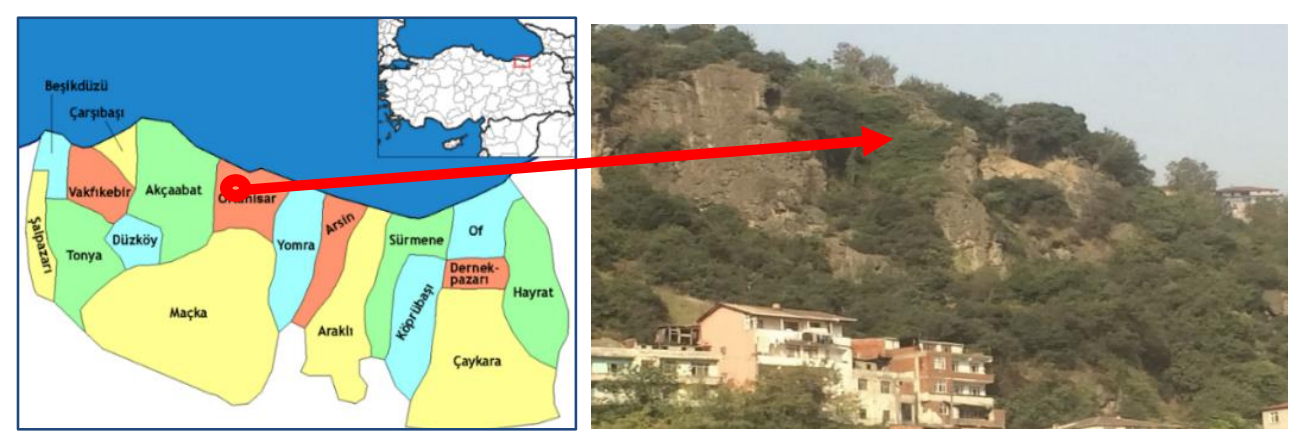

\section{Şekil 3:}

Çalışma alanının yer bulduru haritası ve kaya düşmesi kaynak alanının görünümü

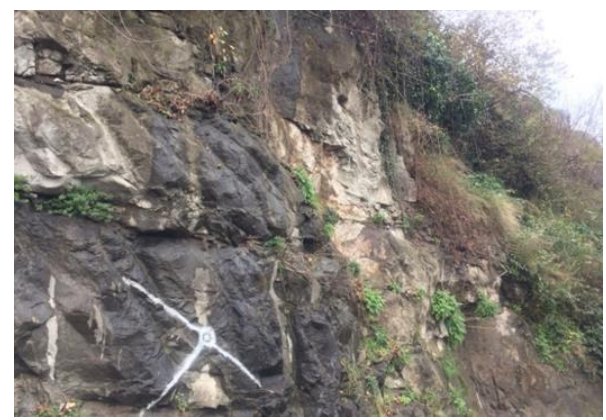

Şekil 4:

Etüt alanı şev yüzeyinde mostra veren Kabaköy Formasyonuna ait bazaltlardan görünüm 
İnceleme alanında yamaç yüzeyinden alınan kayaç örneği üzerinde laboratuvar ortamında birim hacim ağırlık, nokta yükü dayanım indeksi ve tek eksenli basınç dayanım deneyleri yapılmıştır. Deney sonuçları Tablo 1'de verilmiştir. Tablo 1 incelendiğinde incelenen birim tek eksenli basınç direncine göre "orta dayanımlı" kayaç, kaya mukavemet sınıflamasına göre "sağlam kaya (R4), kayaçların ayrışma derecesine sınıflamasına göre ise "az derece" (W) ayrışmış olduğu görülmüştür (ISRM, 2007).

Tablo 1. Araziden alınan kaya numunelerin fiziksel ve mekanik özellikleri

\begin{tabular}{|c|c|c|c|}
\hline $\begin{array}{l}\text { Numune } \\
\text { No }\end{array}$ & $\begin{array}{l}\text { Birim hacim } \\
\text { ağırlığı }\left(\mathbf{k g} / \mathbf{m}^{3}\right)\end{array}$ & $\begin{array}{l}\text { Nokta yükleme basınç } \\
\text { dayanımı }\left(\mathrm{kg} / \mathrm{cm}^{2}\right)\end{array}$ & $\begin{array}{l}\text { Tek eksenli basınç } \\
\text { dayanımı }\left(\mathrm{kg} / \mathrm{cm}^{2}\right)\end{array}$ \\
\hline K-I & 2400 & 42,84 & 514,08 \\
\hline K-II & 2385 & 41,95 & 503,40 \\
\hline K-III & 2456 & 42,73 & 512,76 \\
\hline Ortalama & 2413,66 & 42,50 & 510,00 \\
\hline
\end{tabular}

\subsection{Fotogrametrik Yöntemler ile Arazinin Sayısal Yüzey Modelinin Oluşturulması}

Bölgede dik yamaçlarda ve yoğun bitki örtüsü nedeniyle topografik çalışmaların zor olması ve riskli blokların zor seçilebiliyor olmasından dolayı farklı yöntemlerle harita alımlarının yapılarak ortak bir yorum yapılması gerekliliği ortaya çıkmıştır. Çalışma alanına ait yersel yöntemler ile daha önceki çalışmalarda hazırlanan çeşitli ölçekli haritalar mevcuttur. Fakat bu haritaların yamacın dik bölümlerindeki hassasiyetleri düşük olduğundan ve kaya düşme analizlerinde şev yüzeyin hassasiyeti analiz sonuçlarını doğrudan etkileyeceğinden arazinin fotogrametrik yöntemler ile hassas sayısal yüzey modeli oluşturulmuştur. İnceleme alanın sayısal yüzey modeli oluşturulurken ilk etapta fotogrametrik ilkeler doğrultusunda arazinin topoğrafyasını iyi şekilde temsil edecek homojen dağılıma sahip 14 adet yer kontrol noktası tesis edilmiştir (Şekil 5). Bu noktalar tesis edilirken fotogrametrik çekim sırasında rahatlıkla görülebilmesine, resimlerde bu noktaların görülmesini engelleyecek ağaç ve bina gibi doğal ve yapay nesnelerden uzak olmasına ve konu ile ilgili yönetmelikte belirtilen hususlara dikkate edilmiştir (Yönetmelik, 2005). Fotogrametrik uçuşlarda $20 \mathrm{MP}$ (MegaPixel) çözünürlükte 4K fotoğraf çekebilen 4 pervaneli Phantom 4 PRO tipi insansız hava aracı kullanılmıştır. İnsansız hava aracı ile toplam 43 adet nadir ve 403 adet oblik hava fotoğrafı çekilmiştir (Şekil 6).

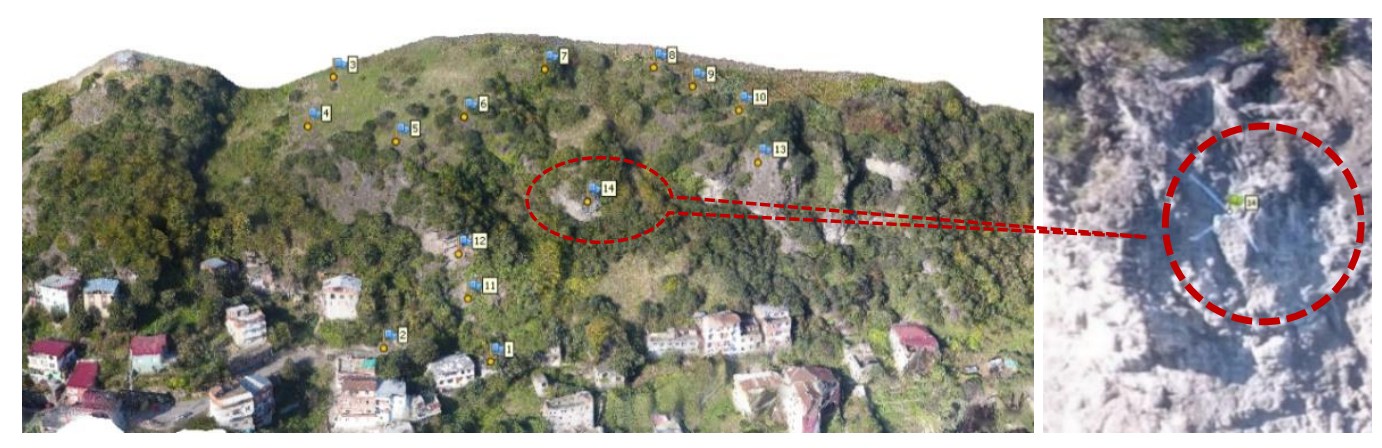

Şekil 5:

Yer kontrol noktalarının sayısal yüzey model üzerindeki konumları 


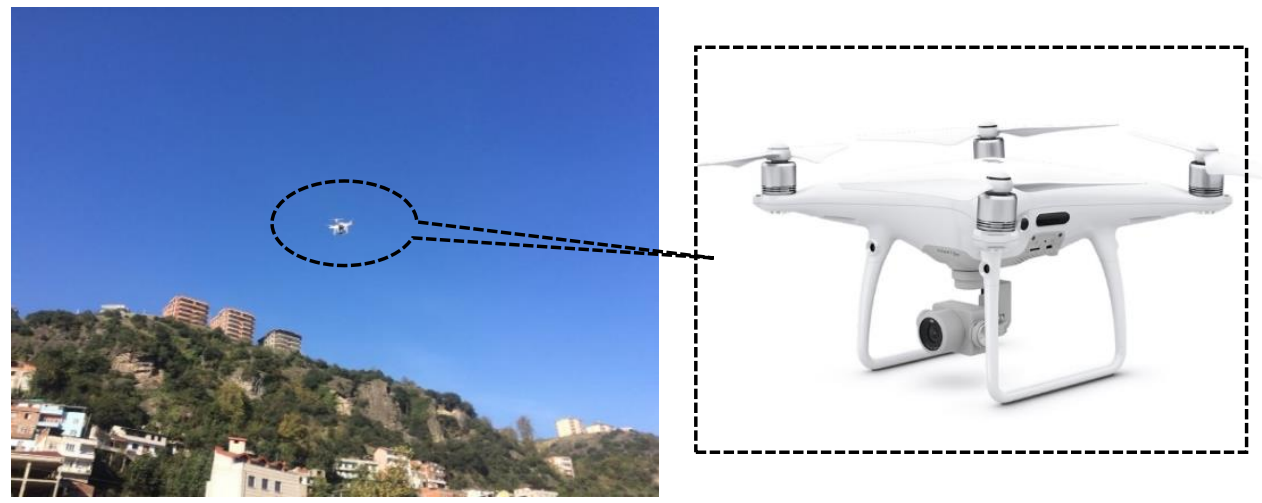

\section{Şekil 6:}

Insansız hava aracının fotogrametrik çekim yapıldığı sıradaki bir görünümü

Kamera ölçümleme değerleri, elde edilen hava fotoğrafları ve yer kontrol noktalarının hassas konumları da kullanılarak fotogrametrik değerlendirme yöntemleri ile karşılaştırılmış, uçuşa konu bölgenin $3,3 \mathrm{~cm}$ çözünürlükte ortofoto (ölçekli fotoğraf) ve nokta bulutları ve bu nokta bulutundan da 3 boyutlu sayısal yüzey modeli üretilmiştir. Elde edilen model ile yer kontrol noktaları arasındaki ortalama sapma miktarı X ekseninde $3 \mathrm{~cm}$, Y ekseninde $3,8 \mathrm{~cm}$, yükseklik değerinde 4,2 cm olarak tespit edilmiştir. Nokta bulutu ve ortofotolar kullanılarak sayısal yüzey modellerine altlık teşkil edecek vektör veriler derlenmiş, bu verilerden sayısal yükseklik modeli ve eş yükselti eğrileri üretilmiştir (Şekil 7,8).

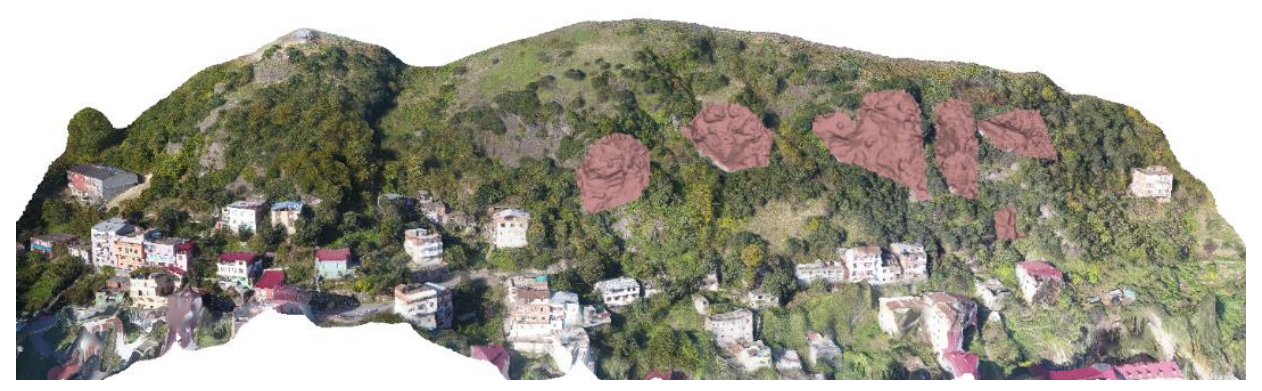

Şekil 7:

Fotogrametrik yöntemler ile elde edilen çalışma alanın 3 boyutlu sayısal yüzey modeli
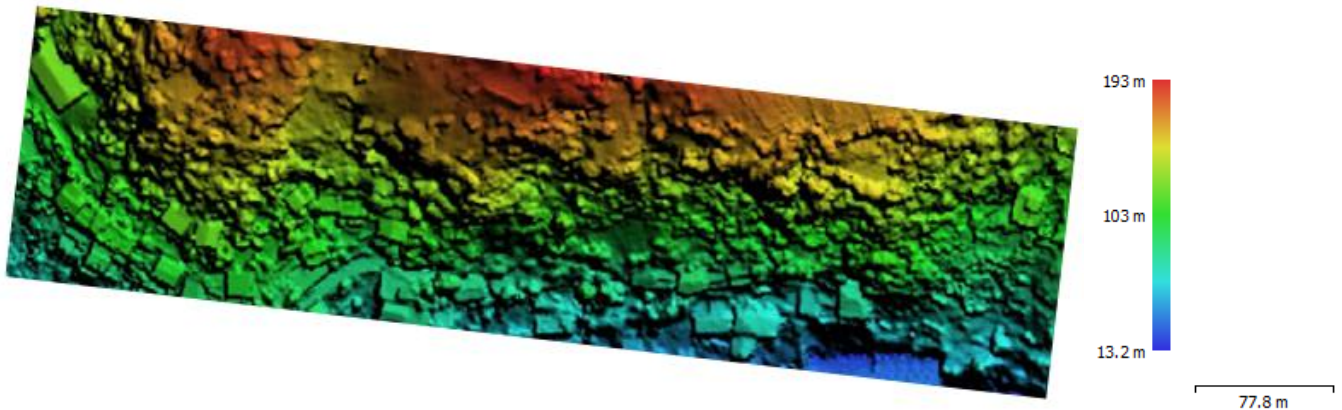

Şekil 8:

Arazi saylsal yükseklik modeli 


\subsection{Riskli Blokların Yakın İncelemesi ve Kaya Düşmesi Risk Tespiti}

Arazinin dik ve eğimli olması nedeniyle düşme ihtimali olan blokların serbest bir şekilde yerinde incelenmesi tehlikelidir. Bu nedenle bu konuda uzmanlaşmış endüstriyel dağcı ekipler tarafından ip ile askıda arazide incelemeler yapılmıştır. İncelemeler sırasında riskli yamaçların farklı açılardan fotoğrafları çekilmiştir. Bu incelemelere ile ilgili örnek birkaç fotoğraf Şekil 9'da verilmiştir. İncelemeler sırasında bitki örtüsü nedeniyle arazide harita alımları sırasında tespit edilememiş blokların ve ana kaya ile bağlantısı kalmamış olanları (1. Derecede riskli bloklar) tespit edilerek haritalara işlenmiştir. Endüstriyel dağcılar tarafından yapılan gözlemlerde yamaç aralarında kalan kısımlarda tehlikeli bloklar yerine daha ziyade önceden düşmüş bloklar görülmüştür. Dik yamaçlarda ise sık sık askıda kalmış veya ana kaya ile bağlantısı kalmamış veya çok az kalmış düşme tehlikesi oldukça yüksek bloklar tespit edilmiş, bu kayaların bir kısmının çeşitli bitkiler ile kaplandığı, bu nedenle görülemediği bilgisine ulaşılmıştır. Bu tarz blokların ve süreksizliklerin detaylı fotoğrafları ve bulundukları konumları yerinde tespit edilmiştir. Genel olarak kaya düşmesine kaynak zonların, yamaçların üst yüzeyleri ile yamacın kuzey bölümündeki etek kısmına yakın sırt üstündeki kesimlerde yoğunlaştığı görülmüştür.
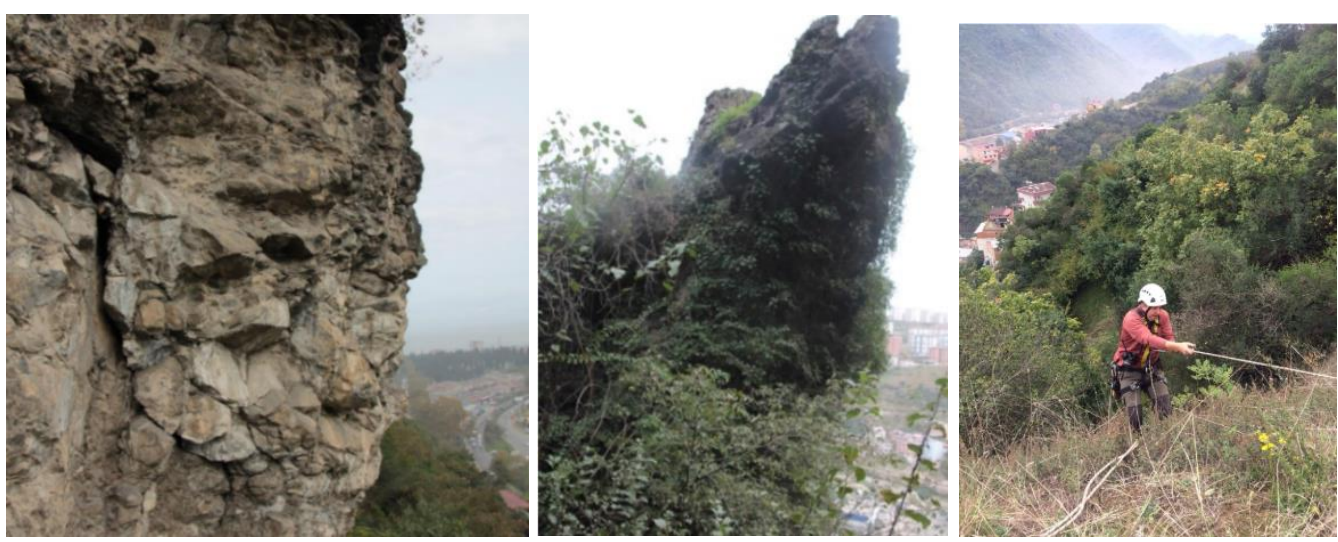

Şekil 9:

Düşme potansiyeli bulunan blokların endüstriyel dağcılar tarafindan elde edilen görüntüleri

\subsection{Kaya Düşme Analizleri}

Çalışmanın bu kısmında kaya düşmesi analiz programı kullanılarak blokların düşme sırasında kazanabilecekleri hız, kinetik enerji ve sıçrama yükseklikleri bilgileri elde edilmiştir. Arazide yapılan çalışmalarda düşme tehlikesi bulunan en büyük kaya bloğunun $4 \mathrm{~m}^{3}$ olduğu görülmüştür. Buna göre $50 \mathrm{~kg}$ ve $10000 \mathrm{~kg}$ olmak üzere iki farklı ağırlığa sahip kaya blokları dikkate alınarak kaya düşme analizleri gerçekleştirilmiştir. Arazi sayısal modeli üzerinde Şekil 10' da gösterildiği gibi 40 farklı kritik kaya düşme güzergâhı belirlenerek topografik kesitleri oluşturulmuştur. Kaya düşme analizleri, oluşturulan kritik düşme güzergâhları boyunca iki boyutlu RocFall yazılımı ile gerçekleştirilmiştir (https://www.rocscience.com/software/rocfall). Kesitlerdeki yamaç özelliği programa tanımlanırken, yamaçtaki durumuna uygun olarak tanımlanmıştır. Kaya düşme analizlerinde normal sürtünme katsayısı $(\mathrm{Rn})$ 0,53 teğetsel sürtünme katsayısı (Rt) 0,99 ve kaya bloklarına ilk hız değeri 0 olarak tanımlanmıştır. Bu değerler RocFall programı tarafından çıplak yüzeye sahip kayalar için önerilmektedir. Kaya düşme analizleri yapıldıktan sonra istatistik analiz programından elde edilen en yüksek sıçrama yüksekliği, kinetik enerji ve hız sonuçları Tablo 2'de verilmiştir. Ayrıca kritik sıçrama yüksekliğine sahip güzergâhlarda kaya düşme analizlerinin detayları Şekil 11'de verilmiştir. 


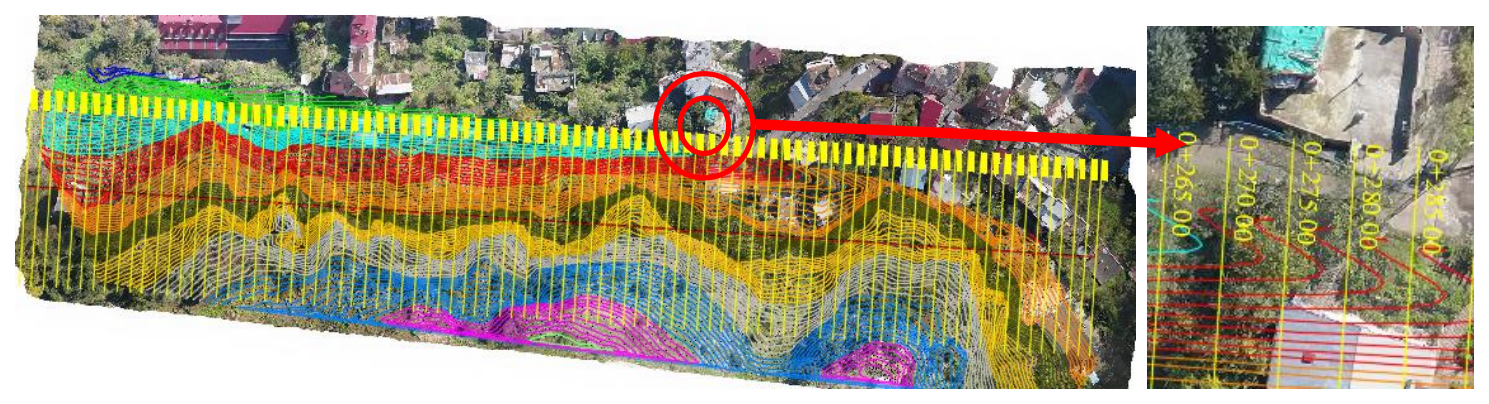

Şekil 10:

Arazi sayısal model üzerinden alınan kesit hatlarının görünümü

Tablo 2. Kaya düşme analizlerinden elde edilen sıçrama, kinetik enerji ve hız değerleri

\begin{tabular}{|c|c|c|c|c|c|c|c|c|c|c|c|}
\hline & Kesit No: & 1. & 2 & 3 & 4 & 5 & 6 & 7 & 8 & 9 & 10 \\
\hline & Ortalama Ĕğim (Derece) & $27^{\circ}$ & $32^{\circ}$ & $33^{\circ}$ & $34^{\circ}$ & $34^{0}$ & $33^{\circ}$ & $33^{\circ}$ & $34^{\circ}$ & $34^{\circ}$ & $35^{\circ}$ \\
\hline & $\mathbf{K m}+\mathbf{m}$ & $0+10$ & $0+15$ & $0+20$ & $0+25$ & $0+30$ & $0+35$ & $0+40$ & $0+45$ & $0+50$ & $0+55$ \\
\hline \multirow{3}{*}{$\begin{array}{l}80 \\
8 \\
8\end{array}$} & Sıçrama Yüksekliği (m) & Güv. & Güv. & 0,2 & 0,05 & 0,03 & 1,03 & 3,5 & 0,08 & 0,075 & 0,04 \\
\hline & Kinetik Enerji $(\mathbf{k J})$ & Güv. & Güv. & 0,3 & 1,5 & 1,7 & 1,31 & 1,4 & 0,7 & 1,1 & 1,87 \\
\hline & Hız $(\mathbf{m} / \mathbf{s})$ & Güv. & Güv. & 3 & 3,75 & 7,9 & 6,9 & 18 & 5,2 & 6,25 & 8,35 \\
\hline \multirow{3}{*}{ 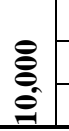 } & Sıçrama Yüksekliği (m) & Güv. & Güv. & 0,01 & 0,05 & 0,03 & 0,96 & 3,5 & 0,05 & 0,08 & 0,025 \\
\hline & Kinetik Enerji (kJ) & Güv. & Güv. & 75 & 310 & 410 & 280 & 2700 & 175 & 260 & 345 \\
\hline & Hiz $(\mathrm{m} / \mathrm{s})$ & Güv. & Güv. & 2,9 & 4,2 & 7,9 & 7,4 & 18 & 5,45 & 6,9 & 7,75 \\
\hline & Kesit No: & 11 & 12 & 13 & 14 & 15 & 16 & 17 & 18 & 19 & 20 \\
\hline & Ortalama Ĕgim (Derece) & $39^{\circ}$ & $41^{0}$ & $42^{\circ}$ & $46^{0}$ & $49^{\circ}$ & $48^{\circ}$ & $48^{\circ}$ & $49^{\circ}$ & $54^{\circ}$ & $59^{\circ}$ \\
\hline & $\mathbf{K m}+\mathbf{m}$ & $0+60$ & $0+65$ & $0+70$ & $0+75$ & $0+80$ & $0+85$ & $0+90$ & $0+95$ & $0+100$ & $0+105$ \\
\hline \multirow{3}{*}{$\frac{90}{80}$} & Sıçrama Yüksekliği (m) & 0,7 & 3,5 & 0,47 & 6,53 & 1,6 & 7,7 & 4,1 & 3,9 & 2,75 & 11,2 \\
\hline & Kinetik Enerji $(\mathbf{k J})$ & 4 & 16,8 & 2,25 & 5,65 & 4,5 & 17 & 13,2 & 13,9 & 8,7 & 12,5 \\
\hline & Hiz $(\mathrm{m} / \mathrm{s})$ & 10,53 & 22,7 & 11 & 14,5 & 12,7 & 23 & 21,5 & 22,2 & 17,5 & 21,7 \\
\hline \multirow{3}{*}{ 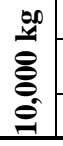 } & Sıçrama Yüksekliği (m) & 0,67 & 3,2 & 0,69 & 6,75 & 1,5 & 6,2 & 3,75 & 4,2 & 3,25 & 11,7 \\
\hline & Kinetik Enerji (kJ) & 695 & 2740 & 510 & 1150 & 890 & 2850 & 2650 & 2750 & 1700 & 2550 \\
\hline & $\operatorname{Hiz}(\mathrm{m} / \mathrm{s})$ & 10,6 & 22,4 & 9,2 & 14,4 & 12,7 & 24 & 22,1 & 23,5 & 17,6 & 22,1 \\
\hline & Kesit No: & 21 & 22 & 23 & 24 & 25 & 26 & 27 & 28 & 29 & 30 \\
\hline & Ortalama Ĕgim (Derece) & $52^{\circ}$ & $42^{\circ}$ & $48^{\circ}$ & $53^{\circ}$ & $52^{\circ}$ & & & & & $49^{\circ}$ \\
\hline \multirow{4}{*}{$\frac{90}{i n}$} & $\mathbf{K m}+\mathbf{m}$ & $0+110$ & $0+115$ & $0+120$ & $0+125$ & $0+130$ & $0+135$ & $0+140$ & $0+145$ & $0+150$ & $0+155$ \\
\hline & Sıçrama Yüksekliği (m) & 10,5 & 5,75 & 1,25 & 5,9 & 10,05 & 3,4 & 10,4 & 9,6 & 0,6 & 2,1 \\
\hline & Kinetik Enerji (kJ) & 12,7 & 9,6 & 6,8 & 11,6 & 11,7 & 11,5 & 13,6 & 12,4 & 5,1 & 7,7 \\
\hline & $\operatorname{Hiz}(\mathbf{m} / \mathbf{s})$ & 21,7 & 18,9 & 15,6 & 21,6 & 21,1 & 20,05 & 22,9 & 21,8 & 12,7 & 16,5 \\
\hline \multirow{3}{*}{ 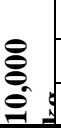 } & Sıçrama Yüksekliği (m) & 10,1 & 6,1 & 0,95 & 6,8 & 11,4 & 3,4 & 8,8 & 8,7 & 0,5 & 1,84 \\
\hline & Kinetik Enerji $(\mathbf{k J})$ & 2350 & 2050 & 1460 & 2550 & 2310 & 2490 & 2410 & 2320 & 1050 & 1630 \\
\hline & $\operatorname{Hiz}(\mathbf{m} / \mathbf{s})$ & 21,2 & 19,5 & 15,3 & 21,6 & 21,5 & 20,7 & 21,4 & 21,1 & 13,1 & 17,1 \\
\hline & Kesit No: & 31 & 32 & 33 & 34 & 35 & 36 & 37 & 38 & 39 & 40 \\
\hline \multirow{5}{*}{$\frac{60}{80}$} & Ortalama Ĕ̆im (Derece) & $45^{\circ}$ & $45^{\circ}$ & $45^{\circ}$ & $43^{\circ}$ & $46^{0}$ & $49^{\circ}$ & $49^{\circ}$ & $50^{\circ}$ & $49^{\circ}$ & $45^{\circ}$ \\
\hline & $\mathbf{K m}+\mathbf{m}$ & $0+160$ & $0+165$ & $0+170$ & $0+175$ & $0+180$ & $0+185$ & $0+190$ & $0+195$ & $0+200$ & $0+205$ \\
\hline & Sıçrama Yüksekliği (m) & 2,23 & 0,4 & 1,67 & 0,1 & 0,05 & 0,1 & 6,7 & 5,8 & 0,4 & 6,6 \\
\hline & Kinetik Enerji (kJ) & 9,1 & 3,1 & 9,9 & 1,1 & 1,9 & 0,9 & 11,5 & 12,2 & 3,6 & 11,1 \\
\hline & $\operatorname{Hiz}(\mathbf{m} / \mathbf{s})$ & 18,1 & 10,25 & 18,8 & 5,6 & 7,4 & 5,4 & 21,2 & 20,2 & 8,6 & 19,4 \\
\hline \multirow{3}{*}{ 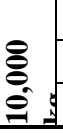 } & Sıçrama Yüksekliği (m) & 2,1 & 0,05 & 0,4 & 0,05 & 0,05 & 0,07 & 5,25 & 5,7 & 0,3 & 6,5 \\
\hline & Kinetik Enerji $(\mathbf{k J})$ & 1810 & 850 & 1440 & 200 & 805 & 340 & 2250 & 2440 & 740 & 2280 \\
\hline & Hiz $(\mathbf{m} / \mathbf{s})$ & 17,2 & 8,1 & 14,5 & 5,4 & 5,5 & 5,3 & 20,6 & 20,6 & 8,6 & 20,6 \\
\hline
\end{tabular}


Nasery M.M.,Çelik M.: Kaya Islahı Çalş. Birleşik Çözümlerin İncelenmesi: Trabzon Kaymaklı Örneği

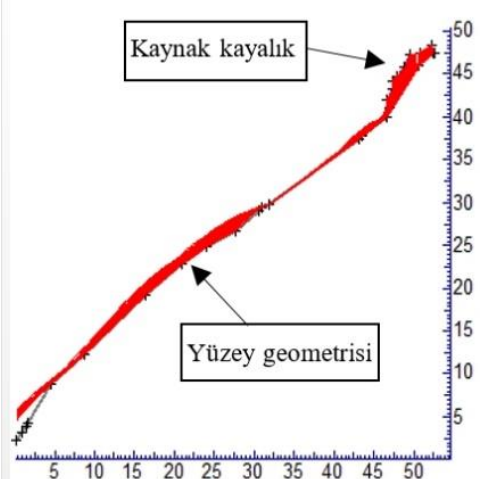

(i)

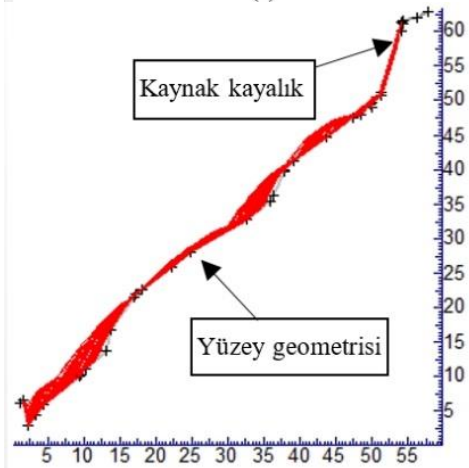

(iv)

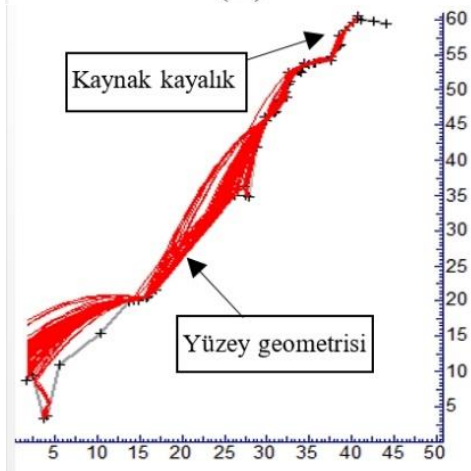

(vii)

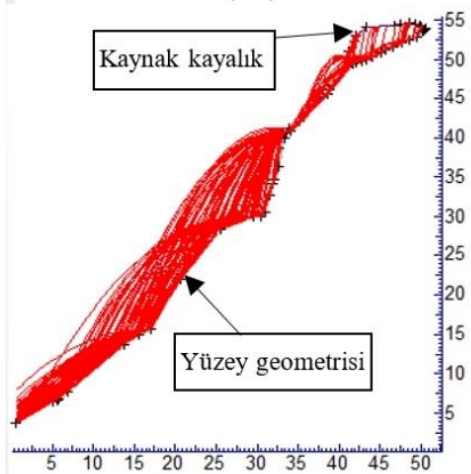

(x)

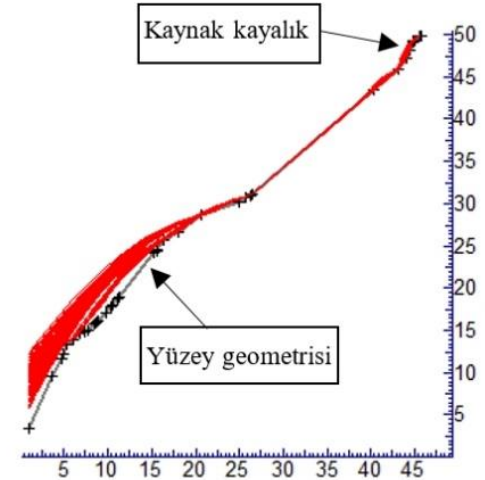

(ii)

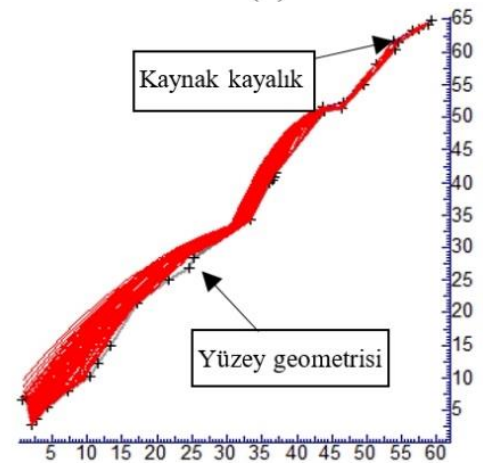

(v)

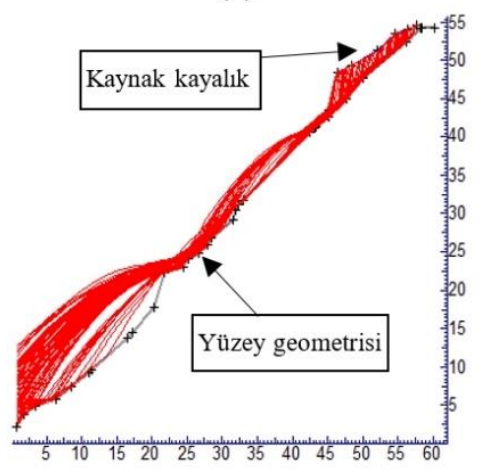

(viii)

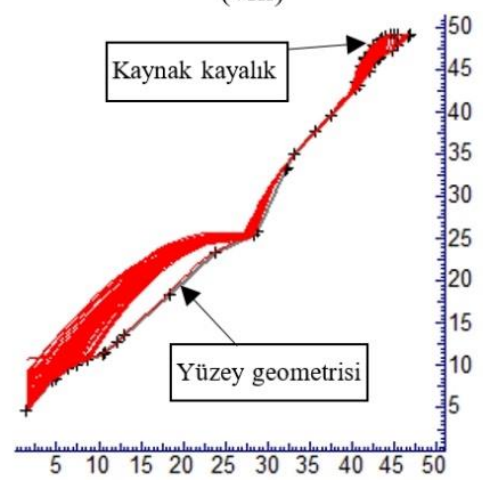

(xi)

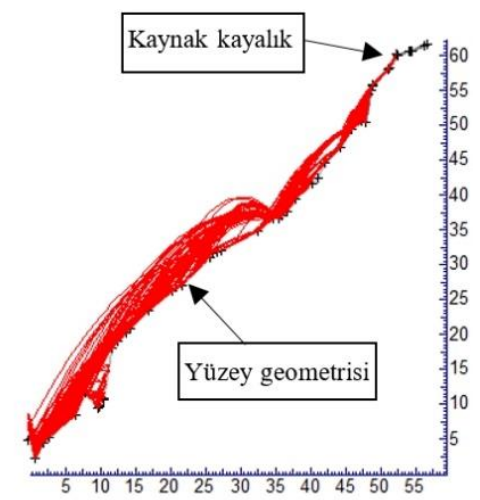

(iii)

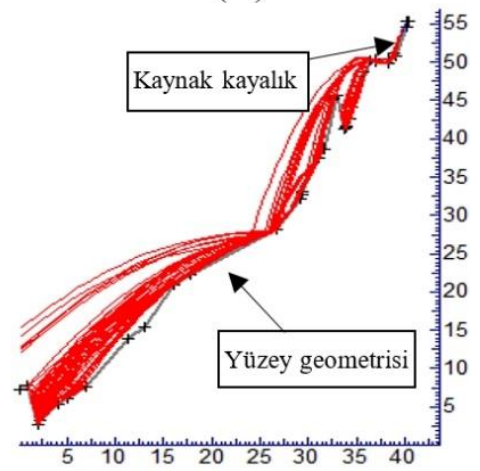

(vi)

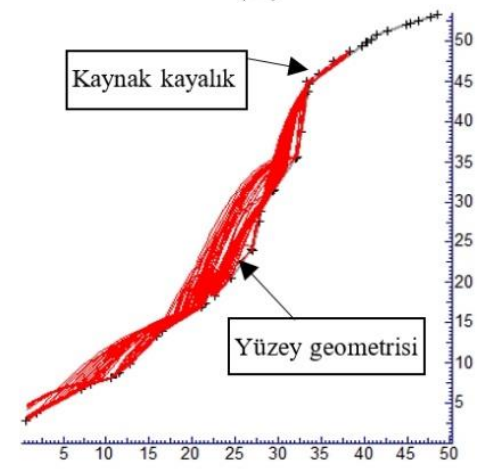

(ix)

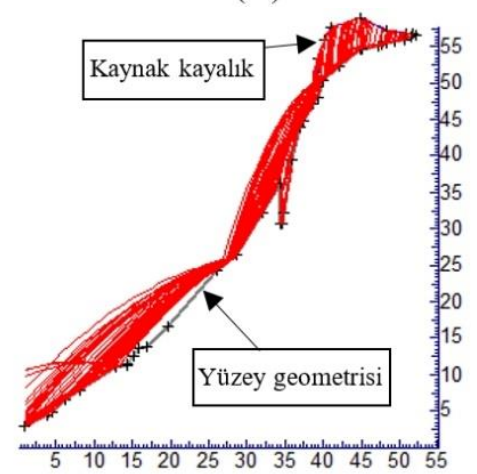

(xii)

Sekil 11:

Kritik kesit hatları boyunca kaya düşme analizleri ve olası sıçrama yükseklik değerleri (m) 


\section{BULGULAR İRDELEMELER}

Kaya düşme analizlerin sonuçları incelendiğinde sıçrama yüksekliklerinin $11,7 \mathrm{~m}$ mertebelerine ulaştığ1 görülmektedir. 40 güzergâhın 12 tanesi 5 metre ve üstü sıçrama yüksekliğine 18 tanesi de $3 \mathrm{~m}$ ve üzeri sıçrama yüksekliğine sahiptir. Bu durum sıçrama yüksekliğinin çalışmanın devamında alınacak kaya ıslahı yöntemi tercihleri için önemini göstermektedir. Ayrıca proje genelinde kinetik enerjilerin alt kotlarda yüksek değerlere ulaştığ 1 ve toplam kinetik enerjinin en yüksek değerin $2850 \mathrm{~kJ}$ olduğu. 40 güzergâh içerisinde 16 tanesinde $2000 \mathrm{~kJ}$ üzerinde olduğu görülmektedir. Son olarak yapılan incelemelerde hız değerinin $23 \mathrm{~m} / \mathrm{s}$ 'yi geçmediği görülmektedir. Hız ve kinetik enerji değerlerinin bu miktarlarda olmasi bariyer yapılması imkânını sağlamaktadır. Eğer değerler daha fazla olsaydı bariyerin delinip geçme veya yetersiz kalma ihtimali de hesaba katılması gerekmekteydi.

Şekil 7 incelendiğinde ve Tablo 2'deki verilere bakıldığında, dik yamaçların aralarında düşük sıçrama yüksekliği veya düşük enerji miktarlarına sahip vadiler görülmektedir. Ancak falezlerden düşebilecek bloklar dik kesitlerde gitmeyip bu güzergâhlara girmesi ihtimali bulunmaktadır. Dik yamaç ve vadiler çok kısa mesafeler içerisinde değişmektedir. Bu ihtimal nedeniyle güzergâh boyunca ayrım yapmadan aynı önlemin alınması gerekmektedir. Kaya düşme analizleri yapılırken, maki veya ağaçlar yok sayılmıştır. Bitkilerin enerji ve hız kesici özellikleri bilinmektedir (Aydın ve Eker, 2017). Ancak bitkilerin hesaba katılmamasının nedeni ise, güvende kalmak (azalacak enerji ve hız projenin güvenlik faktörlerinden biridir) ve daha önce arazide düşen kayalar incelendiğinde grup halinde düşmelere rastlanılmasıdır. Bu tarz kaya düşmelerinde ilk düşen kayalar bitkilere zarar verdiğinden arkadan gelen kayaların bitki engelline takılmadığ görülmüştür. Bu senaryoların arazide gerçekleşme ihtimali vardır.

Çalışma alanında 6 adet tehlikeli dik yamaç ve bu yamaçların arasında bulunan vadilerden oluşan bir topografik yapı vardır. Şekil 5 ve Şekil 7'de görüldügü gibi dik yamaçların alt kotlarında ve üst kotlarında konutlar bulunmaktadır. Bu konutların varlığı önlem yapı türünün seçilmesinde önemli kıstasları oluşturmaktadır. Bu hususlar dikkate alındığında kaya ıslahı metotlarından bazıları arazide kullanılamayacağı veya tek çözüm önerisi olarak sunulamayacağ 1 anlaşılmaktadır. Buna göre; 1slah yöntemlerinden olan düşme riski bulunan blokların kontrollü/kontrolsüz temizliği ve ardından şevde temizleme veya şev eğimi çalışması yapılması, çalışma alanında uygulaması oldukça zordur. Bunun sebebi ise şevin hemen alt kotunda bulunan binaların mevcut olmasıdır. Bu durumda kaya ıslahı çalışma alanının kısıtlı olmasına neden olmaktadır. Dolaysıyla ıslah yönteminin maliyetleri alanın kısıtlı ve zorluğu nedeniyle artıyor olması yukarıda bahis edilen yöntemin tek başına tercih alternatiflerinden çıkartmaktadır. Ancak yöntem içerisinde bulunan kontrollü temizlik özelikle düşme ihtimali oldukça yüksek kayalarda uygulanması kullanılacak diğer yöntemlerin ömürlerinin uzatılması için gerekli olduğu görülmüştür. Hendek, dolgu yapılması gibi çözümler de şev altında yeterli alan bulunmaması ve sıçrama yüksekliğinin fazla olması nedeniyle istenilen boyutta hendek veya dolgu yapılamayacağ nedeniyle tercih edilememiştir. Aynı şekilde toprakarme duvar ile önlem alınması durumunda da benzer sıkıntılar çıkmakta, sıçrama yüksekliği nedeniyle toprakarme duvar boyutları oldukça artmaktadır. Yüksekliği artan toprakarme duvarların taban genişliği de artması gerekmektedir. Bu nedenle arazide yeterli düz yüzeyin olmaması toprakarme duvar çözümlerini de tercih dışına çıkarmaktadır.

Enerji sönümleyici çelik bariyerlerde ise farklı bir durum söz konusudur. İthal ürün olan çelik bariyerlerde yükseklik ve enerji sönümleme kapasitesi artığında maliyetler de oldukça fazla yükselmektedir. Çalışma kapsamında yapılan kaya düşme analizleri ortalama $4 \mathrm{~m}^{3}$ kaya blokları için yapılmış olup en büyük kinetik enerji 2850 kJ olarak hesaplanmıştır. Fakat daha önceki kaya düşme vakaları incelendiğinde, düşen kayaların tek bir blok şeklinde olmayıp grup şeklinde düştügü görülmüsstür. Bu husus göz önüne alındığında yapılacak olan çelik bariyerin en az üç kaya bloğunu tutacak kapasitesinde olan $8550 \mathrm{~kJ}$ kapasiteli olması gerekmektedir. Enerji sönümleyici çelik bariyerleri belirlenmiş standartlara göre test edilmektedir (EOTA, 2008). Bu testler sonucu çelik bariyerlerin maksimum enerji seviye kapasiteleri ve servis enerji kapasiteleri 
belirlenmektedir. Fakat günümüzde çelik bariyerin üretici firmaları ürünlerini pazarlarken maksimum enerji seviyesine göre pazarlamaktadır. Bu da bariyer kapasitelerin belirlemesinde genel bir yanılgıyı oluşturmuş durumdadır. Dolaysıyla bariyerin servis enerji kapasitesine göre belirlenmesi gerekmektedir. Çelik bariyerler ETAG 027 standardına göre A, B ve C olmak üzere üç sınıfa ayrılmaktadır. Şekil 12'de gösterildiği gibi A sınıfı bariyerler maksimum enerji kapasitesine göre, düşen kaya blokları tutuktan sonra deforme edilmiş bariyer yüksekliği ilk yüksekliğin \%50'sinden fazla olması gerekmektedir. Deforme edilmiş bariyer yüksekliği ilk yüksekliğin \%30-50 arasında olması durumunda $\mathrm{B}$ sınıfına girmektedir. C sınıfı bariyer ise maksimum enerji kapasitesindeki çarpmadan sonra deforme edilmiş bariyer yüksekliği, ilk yüksekliğin \%30'undan az olan bariyerlerdir. A sınıfı bariyerler özellik itibari ile C ve B sınıfından daha pahalı bariyerlerdir. Buna göre bariyer yüksekliği belirlemesinde düşen kaya bloklardan sonra olası düşmeler de göz önüne alınarak belirlenmesi gerekmektedir. Dolaysıyla yapılan analiz sonuçları sıçrama yüksekliği problemini çözebilmek için ya pahalı bariyer tipleri seçilmesi gerekmekte veya kriterlere göre en az 12 m yüksekliğine sahip bir bariyerin tercih edilmesi gerekmektedir.

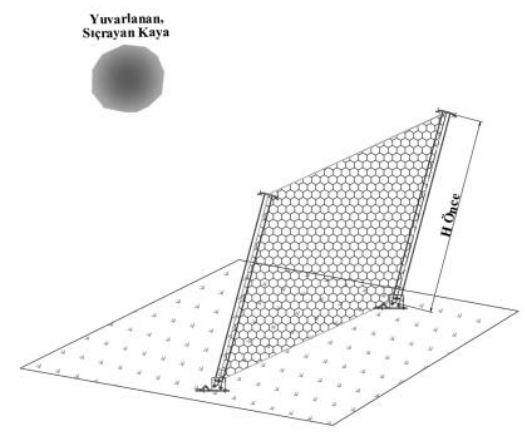

(a)

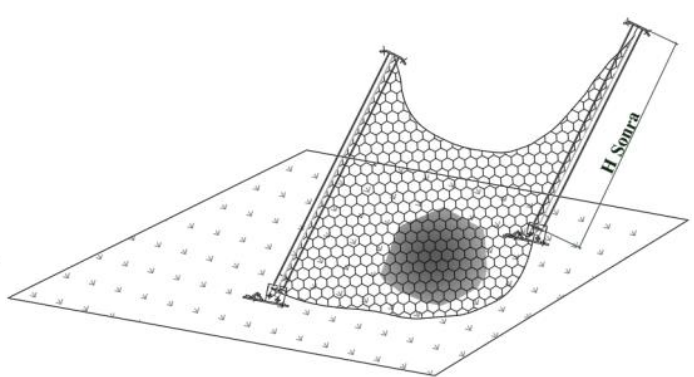

(b)

Şekil 12:

Enerji sönümleyici çelik bariyer etkin yüksekliği kaya düşme deneyinden (a) önce ve kaya düşme deneyinden (b) sonra etkin yükseklik kaybı

Enerji sönümleyici bariyerlerin çalışma prensibine göre esnek olması ve çarpma sırasında arkaya doğru esneyebilmesi gerekmektedir. Bunun için bariyerin yüksekliği kadar arkasında boş bir güvenlik alanın olması gerekmektedir. Bariyer güvenlik alanın içinde herhangi bir nesnenin olmaması gerekmektedir. Daha öncede de belirtildiği gibi yapılan analiz sonuçlarına bakıldığında bariyer yüksekliği en az 12 m olması durumunda arkasında en az 12 m güvenlik mesafesinin bırakılması gerekmektedir. $12 \mathrm{~m}$ güvenlik mesafesi bırakıldığında çok değerli olan çalışma alanındaki arazinin büyük bir bölümü kullanılamaz duruma gelmektedir. Yukarıda bahis edilen kriterler göz önüne alındığında, çalışma alanına sadece çelik bariyerin yapılması kesinlikle uygun olmamaktadır. Kaya düşme ihtimali bulunan alanın tamamen aktif bir güçlendirme ağı ile sabitlenmesi çözüm olarak kabul edilebilir bir yöntemdir fakat bu sistemlerin kaya kütlesine iyi sabitlenmesi gerekmektedir. Zira blokların çelik kafes içinde hareket etmesi çelik ağa baskı uygulamasına ve zamanla yorulma nedeniyle ağ üzerinde yırtılmalara sebep olabilir. Böyle durumların oluşmaması için uzun bulonlar ve iç güçlendirmeler artırılmalıdır. Ayrıca ağ tipi de gelişmiş teknolojik ürünlerden tercih edilmelidir. Yamacın hemen altında bulunan konutlar ağ içinde harekete geçen ancak içeride kalan blokların (debris malzemenin) temizliğine müsaade etmeyeceği de hesaba katıldığında çelik ağ ile yerinde sabitleme metodu da çok maliyetli ve temizleme problemi olan bir yöntem olarak karşımıza çıkmaktadır. Aktif olan müdahale yöntemlerinden biri olan kontrollü veya serbest kaya kırım uygulamasıdır. Bu uygulamada farklı teknikler ile riskli bloklara patlayıcı veya kimyasallar yerleştirilerek kırılması sağlanmaktadır. 
İnceleme alanında kaya kırım uygulaması yapılabilmekte, fakat bu uygulama kontrollü olursa maliyeti aşırı derecede yüksek çıkmaktadır. Çünkü riskli bloğun önce ağ içine sabitlenmesi gerekmekte ve kırım sonrası da endüstriyel dağcılık teknikleri ile bu malzemenin yamaçtan indirilmesi gerekmektedir. Kontrollü kırım yerine serbest kırım yapılaması ise düşme riski bulunan kayaların hemen altına konut, sanayi alanı ve karayolu bulunması nedeniyle oldukça riskli bir yöntem olacağından tercih edilmemiştir.

Güvenlik ve maliyet hususları beraber değerlendirdiğinde kayalar hem aktif hem de pasif korumanın beraber kullanılacağı birleşik bir yapı içerisinde ıslah edilmesi düşünülmüştür. Öncelikle kaya blokların sıçrama yüksekliği problemine çözüm bulmak için pasif bir ağ sistemi ile sıçramalar kontrol altına alınmıştır. Bu ağ normal dayanımlı çelik ağ olmayıp çelik halatlar ile güçlendirilmiş kombine ağ olarak düşünülmüştür. Sistemde kayalar örtü gibi çelik ağ ve halatlar ile sarılacaktır. $\mathrm{Bu}$ örtü gibi olan sargı içerisinde bulonlar bulunmayacak böylelikle düşen kayaların ağ içerisinde hareketine izin verilecektir. Böylelikle bulon maliyetleri olmayacak ayrıca düşen kayalar çelik ağı yorulma etkisinde kalması engellenecektir. Çelik ağların yapılma amacı yuvarlanma sırasında kayanın enerji kazanmasını sınırlandırmak ve sıçrama yüksekliğini kontrol atında tutmaktır. Önerilen kombine ağ içinden kayalar hareket edebileceğinden, olası kaya düşmesinde alttaki konutlara ve yola zarar vermemek için düşen blokların durdurulması gerekmektedir. Bunun için kombine çelik ağın altına riskli bölümlerin bitiminde enerji sönümleyici bariyerin yapılması düşünülmüştür. Fakat bu çelik bariyer sistemi de normal çelik bariyer olmayıp kombine edilmiş kompozit bir sistem olarak tasarlanmıştır. Şekil 13'te gösterildiği gibi $3000 \mathrm{~kJ}$ enerji sönümleyici bariyer 2,5 m yüksekliğine sahip betonarme istinat duvar üzerine montaj edilecektir. Çelik bariyer kolonlarına denk gelen her $10 \mathrm{~m}$ mesafede $70 \times 100 \mathrm{~cm}$ ebatlarında betonarme kolonlar inşa edilecektir. Bu kolonlar çarpma sırasında bariyerin mesnedindeki darbe kuvvetini karşılamak amacıyla tasarlanmıştır. Ayrıca duvarın kaymaması için yapılan tahkikatlarda $50 \mathrm{~cm}$ mesafede çelik bulonlar ile zemine sabitlenmesi yeterli güvenlik katsayıları sağladığı görülmüştür. Böylece $5 \mathrm{~m}$ yüksekliğine sahip bariyerin yüksekliği 7,5 m olacaktır. Hem ekonomik tasarruf sağlanmış olacak hem de aktif sıçrama yüksekliğine karşlık bariyerin aktif yüksekliği artmış olacaktır. Ayrıca istinat duvar arkasındaki toprak malzeme ile oluşturulan ters eğimli alan, düşen blokların bir miktar enerjisini sönümlemesi düşünülmüştür. Bunlara ek olarak çok riskli olan blokların yarı kontrollü kaya kırım uygulaması sırasında düşecek parçaların durmasını sağlayarak güvenli bir şekilde riskleri bertaraf edecektir.

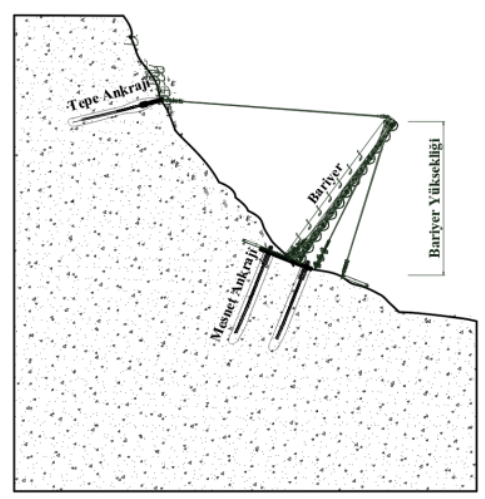

(a)

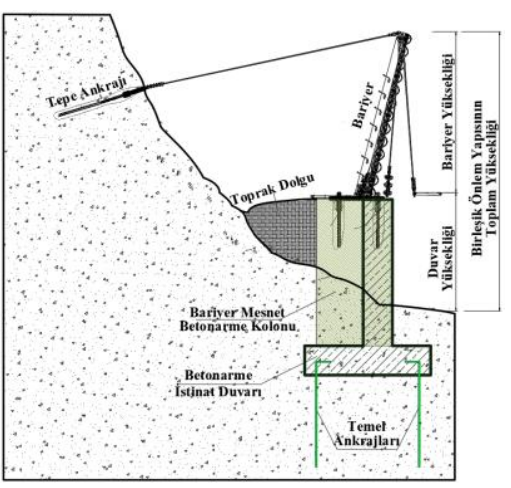

(b)

Şekil 13:

Enerji sönümleyici çelik bariyer (a) geleneksel (b) betonarme istinat duvar üzerine montaj edilecek kompozit bariyer detayl

Arazi etüt çalışmalarının gösterdiği gibi Trabzon İli Ortahisar İlçesi Kaymaklı Mahallesinde bulunan kaya düşmesi nedeniyle afete maruz bölge ilan edilmiş alan dik yamaçların altında fazla 
bir mesafe olmadan konutların başladığı, alt kotlarda sanayi tesisleri ve devlet karayollarının bulunduğu bir alandır. Daha önce düşen bloklar ve etüt çalışmalarında düşme tehlikesi bulunan kayalarda süreksizlikler değerlendirildiğinde $4 \mathrm{~m}^{3}$ hacme ulaşan blokların düşebileceği ve bu blokların düşme sırasında önemli miktarda hız, sıçrama yüksekliği ve kinetik enerji kazanabileceği tespit edilmiştir. Bu incelemeler neticesinde kaya 1slahı projesinde kullanabilecek birçok kaya 1slah yöntemi değerlendirildikten sonra birleşik 1slah yöntemi tasarlanarak önerilmiştir. Şekil 14'te tasarlanan birleşik sslah yönteminin detayı verilmiştir. Bu sistem hem ekonomik hem de güvenlik açısından birçok avantaja sahiptir. Bu avantajların başlıca üç özelliği dikkat çekmektedir;

1.Yüzeyler pasif ağlar ile kaplanacak, ağ altında kayaların düşmesine izin verilecek, ancak ağ vasıtasıyla kayaların düşerken sıçrama yüksekliği ve enerji miktarı kontrol altında tutulacaktır.

2.En altta 5 m yüksekliğinde çelik bariyer yapılacak bu bariyer ağdan gelen enerjisi azalmış olan ve sıçrama yüksekliği sınırlandırılmış olan blokları tutacaktır.

3.Çelik bariyerin daha güvenli yere montajlanabilmesi ve daha yüksek bir yapıda olabilmesi için altına 2,5 m yüksekliğinde betonarme duvar yapılarak duvarın düşen kayalara bakan yüzeyine toprak dolgusu yapılacaktır. Böylelikle gelen kayalar bu toprak nedeniyle betonarme yapıya zarar veremeyecek, bariyer en üst kotu orijinal yer kotundan 7,5 m daha yüksekte olmuş olacaktır.

Yukarıda detayı verilmiş olan proje Trabzon Büyükşehir Belediyesi'ne maliyetleri ile birlikte sunulmuştur. Maliyetlerden bazıları çeşitli kurumların birim fiyatlarından çıkartılmış, bazıları içinde özel pozlar veya piyasa araştırması hazırlanmıştır. Bahsi geçen iş halen ihaleye çıkartılmadığı için maliyet detayları ve projenin diğer detayları paylaşılamamıştır. Proje alternatifi olan başka bir projede ek olarak Trabzon Büyükşehir Belediyesine sunulmuştur. Bu proje öncelikle tehlikeli kayaların tam kontrollü temizliği daha sonra pasif olarak kayaların ağ serilerek tutulması yöntemidir. Bu yöntem, projelendirilen birleşik çözümden yaklaşık 3,2 kat daha pahalıya mal olmaktadır.

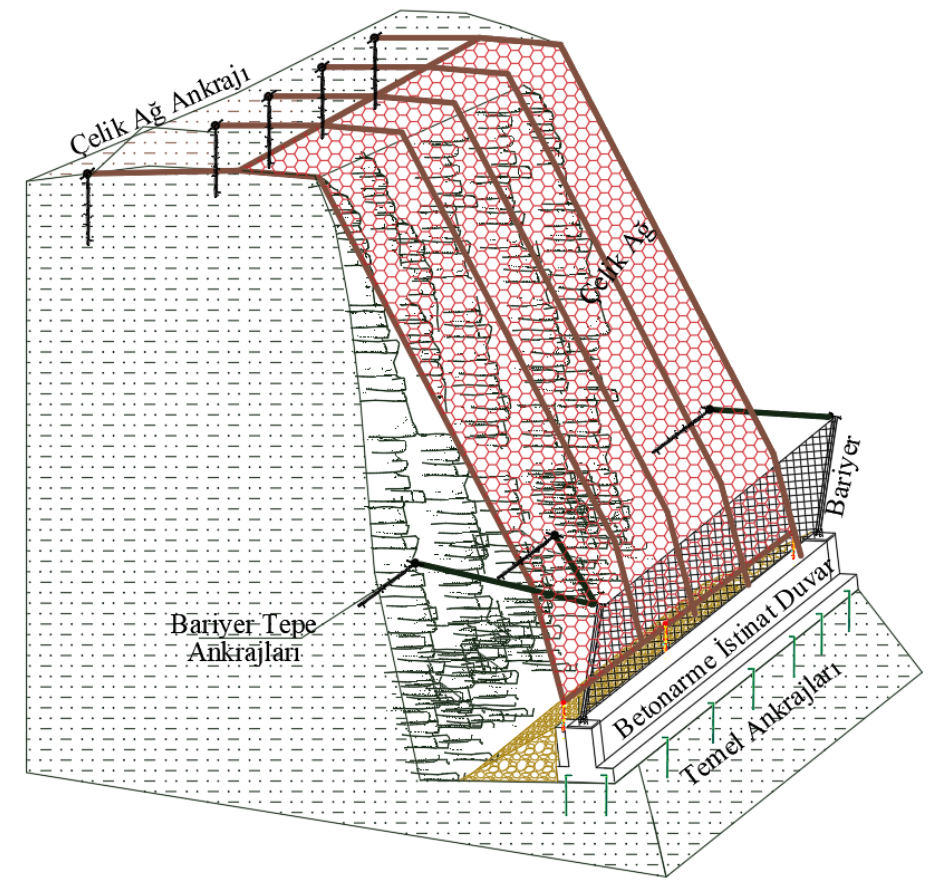

Şekil 14:

Çalışma kapsamında geliştirilen birleşik kaya ıslahı yönetimi 


\section{SONUÇ VE ÖNERILER}

Kaya düşmesi nedeniyle 74 konut ve işyerinin risk altında bulunduğu. Trabzon-Gümüşhane Karayolunu tehlikeye sokabilecek ve sanayi bölgesi olmasından dolayı gün içinde birçok kişinin içinde bulunduğu bu afete maruz bölgede, 1slah projesi yapımı sırasında şu bilgiler elde edilmiştir. 1. Kaya sslahı için birçok yöntem kullanılmaktadır. Ancak kullanılacak yöntemin iyi seçilmesi ve gerekirse farklı yöntemlerin birlikte kullanılması daha güvenli ve ekonomik sonuçlar elde edilmesini sağlamaktadır. Çalışmada kullanılan birleşik yöntem, ekonomik olarak en iyi alternatif projeye oranla 3,2 kat daha uygun maliyetli olduğu görülmüştür. Ayrıca hazırlanan birleşik yöntem, alternatif projeden daha güvenli sonuç vermektedir.

2. Kaya ıslahı projelendirme çalışmaları multidisipliner bir uygulamadır. Farklı mühendislik dallarının ortak katkı sağlaması ıslah yönteminin seçimi ve hesaplarında oldukça büyük faydalar sağlamaktadır. Farklı ıslah metotlarının birleşik hale gelmesi için farklı mühendislik dallarının yorumlarından faydalanması gerekliliği görülmüştür.

3. Trabzon İli Ortahisar İlçesi Kaymaklı Mahallesinde bulunan kaya düşmesi afet alanı içerisinde yapılan incelemelerde yaklaşı $16 \mathrm{~m}$ yükseklikte 6 dik yamaçtan oluşan kaynak kayalıklar ve bu kayalıkların hemen alt kotunda başlayan konutlar tespit edilmiştir. Kaynak kayalıklardan gelen blokların 11,7 m gibi yüksekliklere kadar sıçrayabildiği, yaklaşık 3000 kJ enerji kazanabildiği tespit edilmiştir. Kaya düşmesi sırasında blokların can ve mal kaybına yol açmaması için, konutlar ile kaynak kayalıklar arasına ilk önce istinat duvarı yapılması, daha sonra bu istinat duvarının üzerine enerji sönümleyici esnek çelik bariyer yapılması ve istinat duvarının arkasının kaya çarpması sırasında deforme olmaması için ince malzeme ile doldurulmasına karar verilmiştir. İlk güvenlik önlemi olarak bariyer yapıldıktan sonra düşme potansiyeli bulunan blokların yarı kontrollü yöntemler ile temizlenmesi ve en nihayetinde kaynak kayalıkların üst kotlarından bariyer dibine kadar pasif koruma sağlayacak çelik ağ kaplama yapılması kararlaştırılmıştır.

\section{TEŞEKKÜR}

Bu çalışma kapsamında bilgi ve veri paylaşımında bulunan Trabzon Büyük Şehir Belediyesi, Trabzon ile Afet ve Acil Durum Müdürlüğ̈̈, Dynamica Mühendislik ve Kuzey Dağcılık yetkililerine teşekkür ederiz.

\section{KAYNAKLAR}

1. Admassu, Y., Shakoor, A. and Wells, N. A., (2012) Evaluating selected factors affecting the depth of undercutting in rocks subject to differential weathering, Engineering Geology, 124, 1-11. https://doi.org/10.1016/j.enggeo.2011.09.007

2. Alkan F., Dağ S., (2018) Gümüşhane yöresinde yüzeylenen magmatik kökenli bazı kayaların jeomekanik özellikleri arasındaki ilişkilerin araştırılması, Uludağ University Journal of The Faculty of Engineering , 23 (2) , 203-216 https://doi.org/10.17482/uumfd.409184

3. Andrea L., Monica B., Daniele M., Daniele P., (2016) Maintenance and risk management of rockfall protection net fences through numerical study of deteriorations, Nat. Hazards Earth Syst. Sci. Discuss, 24 March https://doi.org/10.5194/nhess-2016-78

4. Aydin, A., Eker, R., (2017) Forest mapping against rockfalls on a regional scale in Inebolu of Turkey, Journal of the Faculty of Forestry Istanbul University 67(2): 136-149 https://doi.org/10.17099/jffiu.281710

5. Baillifard, F., Jaboyedoff, M., Rouiller, J. D., Couture, R., Locat, J., Robichaud, G. And Gamel, G. (2004) Towards a GIS-based hazard assessment along the Quebec City promontory, Landslide Evaluation and Stabilization (s. 207-213). Canada. https://doi.org/10.1201/b16816-28 
6. EOTA, (2008) Guideline for European technical approval of falling rock protection kits: ETAG 027.

7. https://www.rocscience.com/software/rocfall Erişim Tarihi:24.01.2020 Konu: Rocscience Inc. (2013) RocFall 5.0.

8. Hutchinson, J.N., (1988) Morphological and geotechnical parameters of landsline in relation to geology and hydrogeology, 5th International Symposium on Landslides, 1,3-35, Lausanne,

9. Leroi E., Bonnard Ch., Fell R., McInnes R., (2005) Risk assessment and management state of the art report, Proceeding of the International Conference on Landslide Risk Management. Hungr, Fell, Couture \& Eberhardt (Eds.), A.A. Balkema Publishers, pp. 159-198

10. Matsuoka, N. and Sakai, H. (1999) Rockfall activity from an alpine cliff during thawing periods, Geomorphology, 28, 309-328 https://doi.org/10.1016/S0169-555X(98)00116-0

11. Öztürk, E., Şahinöz, T., (2018) Afet ve acil durum kayıtlarından 50 yılın (1960-2010) analizi: Gümüşhane İli örneği, Gümüşhane Üniversitesi Sağllk Bilimleri Dergisi, 7(1), 94-100

12. Polat, A., Keskin, İ., Denizli, İ. (2016) Kaya düşmesi önleme yöntemlerine bir örnek: Çelik bariyer uygulaması (Gürün-Sarıca), International Symposium on Natural Hazards and Hazard Management 2016 (DAAYS'16), 02-04 March, pp. 395-400, Karabuk-Turkey

13. Biricik, S.A., (2001) Yeryuvarlağı'nda doğal olaylar ve afetler, Marmara Coğrafya Dergisi, S.3, C.1, İstanbul.

14. Şahin, C., ve Sipahioğlu, Ş., (2009), Doğal Afetler ve Türkiye, Ankara: Gündüz Eğitim ve Yayıncilik.

15. Terzaghi, K., (1950) Mechanism of landslides, The Geological Society of America: Application of Geology to Engineering Practice, Berken Volume, pp. 83-123

16. Turner, A.K., Schuster, R.L., (2012) Rockfall characterization and control, Transportation Research Board, National Academy of Sciences, Washington D.C., 658 p. https://doi.org/10.2113/gseegeosci.19.4.398

17. Ulusay, R., Hudson, J.A. (2007) The complete ISRM suggested methods for rock characterization, testing and monitoring: 1974-2006. ISRM Turkish National Group, Ankara.

18. Varnes, D. J. (1978) Slope movement types and processes, In: R. L. Schuster and R. J. Krizek, Eds., Landslides, Analysis and Control, National Academy of Sciences, pp. 11-33.

19. Wei, L., Chen, H., Lee, C., Huang, W., Lin, M., Chi, C and Lin, H. (2014) The mechanism of rockfall disaster: A case study from Badouzih, Keelung, in northern Taiwan, Engineering Geology, 183, 116-126. https://doi.org/10.1016/j.enggeo.2014.10.008

20. Wyllie, D.C., Norrish, N.I., (1996) Stabilization of rock slopes, Landslides investigation and mitigation, Keith Turner and Robert Schuster Ed.,Transportation Research Board Special Report 247, pp. 474-506

21. Yılmaz, I., Y1ldırım, M. and Keskin, I. (2008) A method for mapping the spatial distribution of rockfall computer program analyses results using ArcGIS software, Bulletin of Engineering Geology and the Environment, 67, 547-554. https://doi.org/10.1007/s10064-008-0174-x

22. Yönetmelik (2005) Büyük ölçekli harita ve harita bilgileri üretim yönetmeliği, $T M M O B$ Harita ve Kadastro Mühendisleri Odası, Ankara. 